\title{
Erratum: STAT3 regulated ARF expression suppresses prostate cancer metastasis
}

Jan Pencik, Michaela Schlederer, Wolfgang Gruber, Christine Unger, Steven M. Walker, Athena Chalaris, Isabelle J. Marié, Melanie R. Hassler, Tahereh Javaheri, Osman Aksoy, Jaine K. Blayney, Nicole Prutsch, Anna Skucha, Merima Herac, Oliver H. Krämer, Peter Mazal, Florian Grebien, Gerda Egger, Valeria Poli, Wolfgang Mikulits, Robert Eferl, Harald Esterbauer, Richard Kennedy, Falko Fend, Marcus Scharpf, Martin Braun, Sven Perner, David E. Levy, Tim Malcolm, Suzanne D. Turner, Andrea Haitel, Martin Susani, Ali Moazzami, Stefan Rose-John, Fritz Aberger, Olaf Merkel, Richard Moriggl, Zoran Culig, Helmut Dolznig \& Lukas Kenner

Nature Communications 6:7736 doi: 10.1038/ncomms8736 (2015); Published 22 Jul 2015; Updated 26 Oct 2015

The affiliation details for Jan Pencik are incorrect in this Article. The correct affiliation details for this author are given below: Ludwig Boltzmann Institute for Cancer Research, Waehringerstrasse 13A, 1090 Vienna, Austria.

Clinical Institute of Pathology, Medical University of Vienna, 1090 Vienna, Austria.

This work is licensed under a Creative Commons Attribution 4.0 International License. The images or other third party material in this article are included in the article's Creative Commons license, unless indicated otherwise in the credit line; if the material is not included under the Creative Commons license, users will need to obtain permission from the license holder to reproduce the material. To view a copy of this license, visit http://creativecommons.org/licenses/by/4.0/ 